\title{
Corporate Social Responsibility in India Inc.: Are They Spending Right
}

\author{
Jagannath Mohanty \\ Institute of Management Technology, Nagpur, India
}

Email address:

jmohanty@imtnag.ac.in

To cite this article:

Jagannath Mohanty. Corporate Social Responsibility in India Inc.: Are They Spending Right. Journal of Investment and Management. Vol. 4, No. 1, 2015, pp. 9-13. doi: 10.11648/j.jim.20150401.12

\begin{abstract}
In a landmark legislation new companies bill was passed in 2013. The scholars and practitioners welcomed the bill with unprecedented enthusiasm and fanfare. Some even claimed it to be the most progressive bill ever passed in the history of independent India. Amongst many provisions, one that has caught maximum attention is a $2 \%$ mandatory spending on CSR activities for companies making Rs. 5 Crores (USD 800,000 approx) or more in profits after tax. One should have the courage to cast a doubt on the good intent and immense possibilities that this legislation offers. Yet, going by the history of businesses in India, both public and privately owned enterprises have been quite reluctant to spend on the social initiatives. Even though the bill appears very promising in its intent, it is not very apparent how the businesses will respond to it. The paper brings out the patterns of large corporate spending on social activities in the past to assess the sector preference of businesses, to somewhere assess are they appending right.
\end{abstract}

Keywords: Corporate Social Responsibility (CSR), Social Spending \& CSR Activities

\section{Introduction}

A relatively discretionary activity, CSR initiatives has been traditionally a owner driven activity for the corporate. CSR has mostly been considered a charity/philanthropy work without attaching any strategic significance of it in company survival and growth. Therefore the companies have put in very little effort to make CSR a goal driven activity. CSR always lacked the missionary zeal to give back to the society. In most cases it has been a eyewash. What needs to be seen in the years to come is the response of the businesses to this legislation. Like most legislations this bill too is going to struggle to achieve its objectives. While it is widely predicted that if companies spend the CSR funds as envisaged in the bill, can impact and improve lives of millions of needy people and make this world a better place to live. During the last three decades, there have been growing interests on quantifying the costs and benefits of CSR among corporations. Springkle and Maines (2010) in recent studies have provided ample evidence that there are immediate costs involved CSR in that includes immediate cash outflows and opportunity cost of spending on CSR that could have been channeled to more profitable activities, at the same time benefits of CSR accrues over a period of time including tax deductions, public image, a means of attracting, motivating and retaining talented employees, and mitigating firm related risks. Therefore the benefits expected from CSR activities to large extent depends on the investment choices the firm makes in the social sphere. The paper makes an attempt to analyze the investment trends of large Indian industrial sectors in CSR activities therefore bringing out the trend and expected outcomes of such spend.

It has been ironical that India has been placed in the league of very poor nations though it's businesses have grown many folds in the past years having acquired some of the largest corporations globally, and being a home to some of the biggest technology, manufacturing and petrochemical corporations of the world.

\section{History of CSR in India}

India has a long rich history of close business involvement in social causes for national development. In India, CSR is known from ancient time as social duty or charity, which through different ages is changing its nature in broader aspect, now generally known as CSR. From the origin of business, which leads towards excess wealth, social and environmental issues have deep roots in the 
history of business. India has had a long tradition of corporate philanthropy and industrial welfare has been put to practice since late 1800 s. Historically, the philanthropy of business people in India has resembled western philanthropy in being rooted in religious belief. Business practices in the 1900 s that could be termed socially responsible took different forms: philanthropic donations to charity, service to the community, enhancing employee welfare and promo ting religious conduct. Corporations may give funds to charitable or educational institutions and may argue for them as great humanitarian deeds, when in fact they are simply trying to buy community good will. The ideology of CSR in the 1950s was primarily based on an assumption of the obligation of business to society.

In initial years there was little documentation of social responsibility initiatives in India. Since then there is a growing realization towards contribution to social activities globally with a desire to improve the immediate environment. It has also been found that to a growing degree companies that pay genuine attention to the principles of socially responsible behavior are also favored by the public and preferred for their goods and services. This has given rise to the concept of CSR. In which industrial and business enterprises can contribute to public welfare beyond the scope of their normal activities. It is generally expected advised that apart from the obvious one of donating funds to good causes which has been their normal practice for years; they could have used their own financial, managerial and human resourced to provide task forces for undertaking direct relief and reconstruction measures. Slowly, it began to be accepted, at least in theory that business had to share a part of the social overhead costs. Traditionally, businesses have discharged its responsibility to society through spending in education, medical facilities, and scientific research among other. Importantly the industry accepted social responsibility as part of the management of the enterprise itself. The community development and social welfare program of the premier Tata Company, Tata Iron and Steel Company (TISCO) was one of the firsts to term its social initiatives as "Social Responsibility".

According to Infosys founder, Narayan Murthy, "social responsibility is to create maximum shareholders value working under the circumstances, where it is fair to all its stakeholders, workers, consumers, the community, government and the environment." Following are the phases of CSR evolution in India.

\subsection{Ethical Model (1930 - 1950)}

One significant aspect of this model is the promotion of trusteeship that was revived and reinterpreted by Gandhiji. Under this notion the businesses were motivated to manage their business entity as a trust held in the interest of the community. The idea prompted many family run businesses to contribute towards socioeconomic development. The efforts of Tata group directed towards the well being of the society are also worth mentioning in this model.

\subsection{Statist Model (1950 - 1970s)}

Under the aegis of Jawahar Lal Nehru, this model came into being in the post-independence era. The era was driven by a mixed and socialist kind of economy. The important feature of this model was that the state ownership and legal requirements decided the corporate responsibilities.

\subsection{Liberal Model (1970s - 1990s)}

The model was actively advocated by Milton Friedman. The model largely surges that corporate responsibility is not the primary responsibility of the businesses, it recommends instead corporate be confined to its economic bottom line. This implies that it is sufficient for business to obey the law and generate wealth, which through taxation and private charitable choices can be directed to social ends.

\subsection{Stakeholder Model (1990 - Present)}

The model came into existence during 1990s as a consequence of realisation that with growing economic profits, businesses also have certain societal roles to fulfill. The model expects companies to perform according to "triple bottom line" approach. The businesses are also focusing on accountability and transparency through several mechanisms CSR needs to be understood within this context captured in the development oriented CSR framework.

\section{The Conceptual Model}

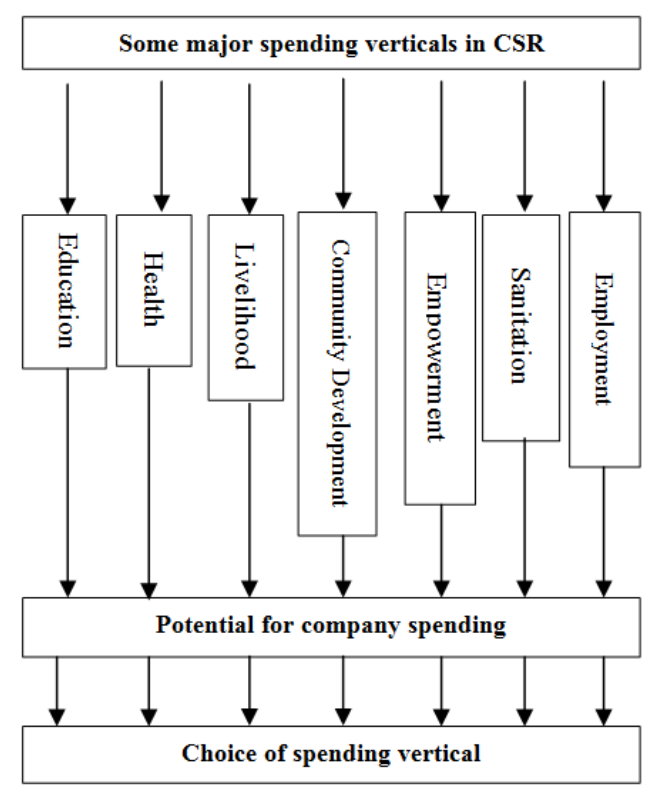

Figure 1. The Conceptual Model

The model suggests a range of spending vertical in CSR for organizations. Hence giving the companies a choice to either pick a single vertical or spend on a portfolio of CSR verticals to maximize the social impact. It has been often seen that many companies tend to choose similar verticals to spend therefore parking money in space, leaving other verticals neglected. 


\section{Literature Review}

In early 1950's \& 60's the literature was not heavily represented in CSR discourse. However, this decade 'marked a significant growth in attempts to formalize, or more accurately, state what CSR means' Carroll (1999). According to Carroll, "CSR encompasses the economic, legal, ethical and discretionary (philanthropic) expectations that society has of organizations at a given point in time. Howard Bowen in 1953 argued that since social institutions shaped economic outcomes it was to be expected that business firms as an economic outcome of societal interests should consider the social impact of business activity. This operational view of CSR is reflected in a firm's social performance, which can be assessed by how a firm manages its societal relationships, its social impact and the outcomes of its CSR policies and actions Wood (1991). Social reporting and social audits are examples of how firms can assess their social performance. In 1960's Keith Davies argued that CSR refers to 'the firm's consideration of, and response to, issues beyond the narrow economic, technical and legal requirements of the firm' Davies (1973). Frederick in 1960 stated 'Social responsibility means that businessmen should oversee the operation of an economic system that fulfills the expectations of the people. And this means in turn that the economy's means of production should be employed in such a way that production and distribution should enhance total socioeconomic welfare' Fredrick (1960). Thus, the definitions of CSR in 1960's were an attempt to link society and businesses, defining society in broadest terms.

Researchers have also studied the impact of CSR activities on financial and non financial performance of the firm. They have found evidence that CSR contributes in lowering cost of equity Dhaliwal et al. (2011), lower borrowing cost Goss and Roberts (2011), higher analyst following Hong and Kacperczyk (2009), more favorable analysts recommendation Ioannou and Serafeim (2010), higher analyst forecast accuracy Dhaliwal et al. (2012), increased financial communications to shareholders Fieseler (2011), more effective corporate governance, and higher firm value (Waddock and Graves 1997; Blazovich and Smith 2011; Jo and Harjoto 2011, 2012).

Harold Johnston (1971) stated that 'a socially responsible firm is one whose managerial staff balances a multiplicity of interests instead of striving only for larger profits for its stockholders. Lee 1997 stated CSR refers to a company's commitment to operate in an economically and environmentally sustainable manner, while acknowledging the interests of a variety of stakeholders and maximizing economic, social and environmental value," The term corporate social performance was first coined by Sethi (1975), expanded by Carroll (1979), and then refined by Wartick and Cochran (1985). In Sethi's 1975 three-level model, the concept of corporate social performance was discussed, and distinctions made between various corporate behaviors. Sethi's three tiers were 'social obligation (a response to legal and market constraints); social responsibility (Congruent with societal norms); and social responsiveness (adaptive, anticipatory and preventive). This has been driven both internally by corporate will and externally by increased governmental and public expectations Mohan (2001). An ideal CSR has both ethical and philosophical dimensions, particularly in India where there exists a wide gap between sections of people in terms of income and standards as well as socio-economic status Bajpai (2001).

\section{Analysis}

A look at top 35 companies of India (Refer table 1) reveals that only 6 or $15 \%$ of the companies spend more than $2 \%$ of their profits ( $\%$ of PAT) which is quite surprising given the fact that companies have long been claiming on its social investment programs and their commitment to meeting the social objectives. Whereas the companies bill 2013 mandates $2 \%$ compulsory contribution from the profits after tax, which amounts to close to 8,000 crores (USD 1.3 Billions approx) (Refer to table 2) alone from the top 500 companies. Yet it is ironical that most spending companies predominantly spend on two social activities education and health. Therefore leaving a host of other social investment avenues neglected.

Table 1. Spending profile of 20 large corporations of India

\begin{tabular}{lll}
\hline Sr. no \& Rank & Company & CSR Activities \\
\hline 1 & Indian Oil corporation limited & $\begin{array}{l}\text { One time LPG connection scheme for rural households, developing tourist amenities at major tourist } \\
\text { spots, sanitation, health care, scholarship scheme \& environment protection. }\end{array}$ \\
2 & Reliance Indusries & $\begin{array}{l}\text { Education, Community healthcare, Community safety initiative, Community environment initiative, } \\
\text { Rural development, Livelihood support program, }\end{array}$ \\
3 & Bharat Petroleum Corporation & $\begin{array}{l}\text { Rural Health, Community development, Education, Social enablement, Water conservation, Health, } \\
\text { Women Empowerment, Child grooming, Women empowerment, Safety education }\end{array}$ \\
4 & Limited & Vocational training, Rural retail scheme for petroleum products, Community kitchen program, Rural \\
5 & Hindustan Petroleum & Health, Girl child scheme \\
6 & Corporation Limited & Rural and community health, Rural education, \\
7 & Tata Motors & Health, Education, Employability, Environment \\
8 & Oil and Natural Gas Company & Assistance in Government programs, Health care, Sanitation, Drinking water project, Rural energy \\
9 & State Bank of India & Community Health, Preservation of tribal culture, Sustainable livelihood, Healthcare, Employment, \\
Employability, Empowerment \& Sports
\end{tabular}




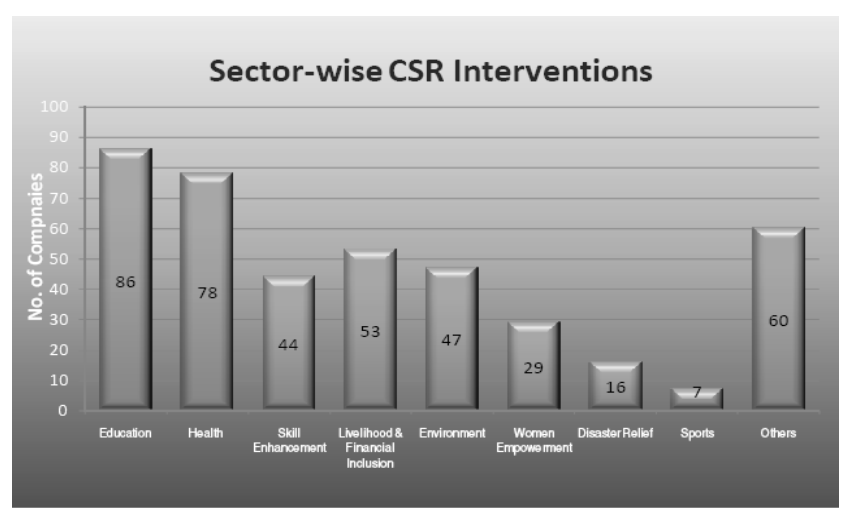

Figure 2. Sector wise spending on CSR

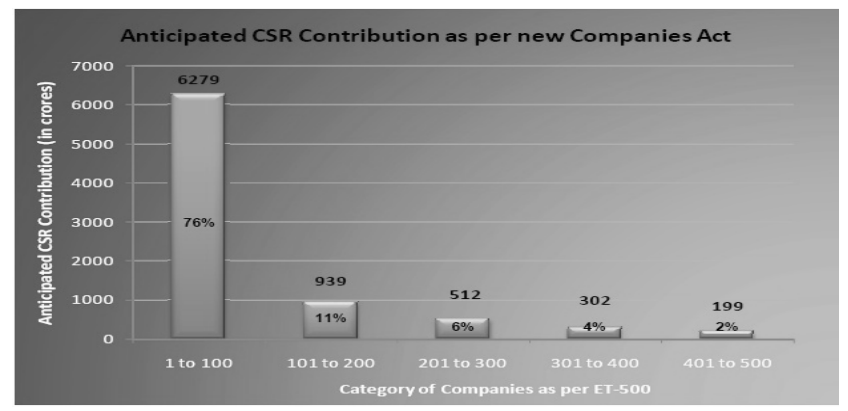

Figure 3. Expected spending on CSR by large corporations

\section{Conclusion}

Therefore it can be concluded with some affirmation that companies spend consistently on similar activities leaving aside some social priorities unattended hence leaving certain sections of the stakeholders uncovered under huge social spending of the India Inc. Since future of organizations largely depends on the kind of social investment choices they make and the partners involved in the decision making process of such investments. Divergent stakeholder theory (Freeman, 1999) suggests the idea that investing time and other resources in addressing stakeholders' interests is a justifiable managerial activity. Therefore for managers and firms seeking to serve the social mandate must adopt a multi stakeholder participation in its social investment plans and processes and make investment choices keeping an eye on social priorities and need of the larger stakeholder interests.

\section{References}

[1] Bajpai, G.N. (2001), "Corporate Social Responsibility in India and Europe: Cross Cultural Perspective", available at: http://www.ficci.com (accessed 12 January 2009)

[2] Blazovich, J., \& Smith, M. (2011). Ethical corporate citizenship: Does it pay? In C. Jeffrey (Ed.), Research on professional responsibility and ethics in accounting (research on professional responsibility and ethics in accounting) (Vol. 15, pp. 127-163). Bingley: Emerald Group Publishing Limited.
[3] Bowen H R (1953), Social Responsibilities of the Businessman, Harper \& Row, New York.

[4] Carroll Archie B. (1979), "A three-dimensional conceptual model of corporate performance", Academy of Management Review, Vol. 4, No. 4

[5] Carroll, A.: 1999, ‘Corporate Social Responsibility', Business and Society Vol. 38 , No. 3

[6] Davis, K. (1973), "The case for and against business assumption of social responsibilities," Academy of Management Journal, vol. 16, No. 4

[7] Davis, K. (1973). The case for and against business assumption of social responsibilities. Academy of Management journal, 16(2), 312-322.

[8] Dhaliwal, D., Li, O., Tsang, A., \& Yang, Y. (2011). Voluntary nonfinancial disclosure and the cost of equity capital: The initiation of corporate social responsibility reporting. Accounting Review, 86(1), 59-100.

[9] Dhaliwal, D., Radhakrishnan, S., Tsang, A., \& Yang, Y. (2012). Nonfinancial disclosure and analyst forecast accuracy: International evidence on corporate social responsibility (CSR) disclosure. Accounting Review, 87(3), 723-759.

[10] Fieseler, C. (2011). On the corporate social responsibility perceptions of equity analysts. Business Ethics: A European Review, 20(2), 131-147.

[11] Frederick, W. (1960), "The growing concern over business responsibility," California Management Review, vol. 2, No. 4

[12] Freeman, R. E. (1999). Divergent stakeholder theory. Academy of management review, 24(2), 233-236.

[13] Goss, A., \& Roberts, G. (2011). The impact of corporate social responsibility on the cost of bank loan. Journal of Banking \& Finance, 35, 1794-1810.

[14] Hong, H., \& Kacperczyk, M. (2009). The price of sin: The effects of social norms on markets. Journal of Financial Economics, 93, 15-36.

[15] Ioannou, I., \& Serafeim, G. (2010). The impact of corporate social responsibility on investment recommendations. Harvard Business School Working Paper No 11-017. http://www.hbs.edu/ research/pdf/11-017.pdf

[16] Jo, H., \& Harjoto, M. (2011). Corporate governance and firm value: The impact of corporate social responsibility. Journal of Business Ethics, 103(3), 351-383.

[17] Jo, H., \& Harjoto, M. (2012). The causal effect of corporate governance on corporate social responsibility. Journal of Business Ethics, 106(1), 53-72.

[18] Mohan, A. (2001), "Corporate citizenship: perspectives from India," Journal of Corporate Citizenship, vol. Summer, No. 2

[19] Philip L. Cochran (2007), The evolution of corporate social responsibility, Business Horizons, Vol. 50, No. 1

[20] Sethi S. P. (1975), "Dimensions of corporate social performance: An analytical Framework", California Management Review, Vol. 17, No. 3

[21] Springkle, G., \& Maines, L. (2010). The benefits and costs of corporate social responsibility. Business Horizon, 53, 445-453. 
[22] Springkle, G., \& Maines, L. (2010). The benefits and costs of corporate social responsibility. Business Horizon, 53, 445-453.

[23] Steven L. Wartick and Philip L. Cochran, The Evolution of the Corporate Social Performance Model, The Academy of Management Review, Vol. 10, No. 4

[24] Waddock, S., \& Graves, S. (1997). The corporate social performance- financial performance link. Strategic Management Journal, 18, 303-319. Whole Foods Mark
[25] Wartick, S. L., \& Cochran, P. L. (1985). The evolution of the corporate social performance model. Academy of management review, 10(4), 758-769.

[26] Wood, D.: 1991, 'Corporate Social Performance Revisited', The Academy of Management Review 16, No. 4 